\title{
Opinion and Special Articles: Remote Evaluation of Acute Vertigo
}

Strategies and Technological Considerations

Kemar E. Green, DO, Jacob M. Pogson, MClinAud, PhD, Jorge Otero-Millan, PhD, Daniel R. Gold, DO, Nana Tevzadze, MD, PhD, Ali S. Saber Tehrani, MD, David S. Zee, MD, David E. Newman-Toker, MD, PhD, and Amir Kheradmand, MD

Neurology ${ }^{\circledR}$ 2021;96:34-38. doi:10.1212/WNL.0000000000010980

\section{Abstract}

Patients with acute vestibular disorders are often a diagnostic challenge for neurologists, especially when the evaluation must be conducted remotely. The clinical dilemma remains: Does the patient have a benign peripheral inner ear problem or a worrisome central vestibular disorder, such as a stroke? The use of a focused history and the virtual HINTS (head impulse test, nystagmus evaluation, and test of skew) examination are key steps towards correctly diagnosing and triaging the acute vertiginous patient. When looking for signs of vestibuloocular dysfunction, there are important technological and practical considerations for an effective clinical interpretation.

\author{
Correspondence \\ Dr. Green \\ kgreen66@jhmi.edu
}

\section{MORE ONLINE}

- Videos

\section{COVID-19 Resources}

For the latest articles, invited commentaries, and blogs from physicians around the world NPub.org/COVID19

From the Departments of Neurology (K.E.G., J.M.P., J.O.-M., D.R.G., N.T., A.S.S.T., D.S.Z., D.E.N.-T., A.K.), Otolaryngology-Head and Neck Surgery (D.R.G., D.S.Z., D.E.N.-T., A.K.), Ophthalmology (D.R.G., D.S.Z., D.E.N.-T.), Emergency Medicine (D.R.G.), Neurosurgery \& Medicine (D.R.G.), and Neuroscience (D.S.Z.), The Johns Hopkins University School of Medicine, Baltimore, MD; and School of Optometry (I.O.-M.), University of California, Berkeley.

Go to Neurology.org/N for full disclosures. Funding information and disclosures deemed relevant by the authors, if any, are provided at the end of the article. 
Dizziness is a loosely used term that can imply different types of internal sensations. With over 4 million annual emergency department "dizzy" visits annually, ${ }^{1}$ it is imperative to promptly differentiate between benign and sinister etiologies while avoiding unnecessary testing or diagnostic errors. The groundwork has been laid with easy-to-use video-oculography (VOG) goggles equipped with high-speed cameras and motion sensors capable of tracking eye and head positions. These portable VOG devices are key tools used by vestibular experts for "tele-dizziness" consultation services, ${ }^{2}$ a true value for practices without in-house access to subspecialty care.

The restraints imposed by social distancing during the pandemic have shifted patients' attitudes towards seeking medical care when ill. Consequently, we must rely on telehealth platforms while patients remain at home. This new norm demands a focused evaluation that can rapidly triage patients. ${ }^{3}$ This is particularly important in patients with acute vestibular symptoms, because the pressing question is whether the underlying cause is anatomically peripheral and likely benign, or central and potentially life-threatening.

Here we outline a focused practical approach that can be applied to remotely perform the clinical examination in the acutely dizzy patient, while highlighting different strategies and technological considerations.

\section{Technological Considerations}

The rapid implementation of video applications has facilitated both synchronous (online with patient and doctor interacting) and asynchronous (offline evaluation of the patient video by the doctor) encounters. The process is influenced by the device type, audiovisual platform, broadband, and the technological aptitude of the users. ${ }^{4,5}$ These elements determine the video quality, as they affect the resolution, frame rate, and data transfer rate of the video connections. There are strategies that patients can use to mitigate problems regarding video quality. Two simple yet crucial issues that can be addressed are the eye-to-camera distance and illumination of the eyes. In general, a well-focused close-up view of the eyes will provide higher resolutions with increased pixel density of the relevant image details. ${ }^{6}$ Similarly, better lighting conditions improve the quality of the images.

It is often difficult to modify the frame rate (i.e., the number of frames per second $[\mathrm{fps}]$ ) or data transfer rate (i.e., the amount of data transmission or bit rate), as these specifications are usually fixed. Some of the best strategies to address data transfer issues include using high-speed Internet connections and avoiding platforms that only allow low data transfer rates. Geography and socioeconomic status often limit the speed of Internet connectivity and the quality of the telemedicine platforms. ${ }^{7}$ Preliminary simulations suggest that the frame rate of the video stream should be at least $60 \mathrm{fps}$ to reliably capture abnormal eye movements such as nystagmus (figure 1).
When using smartphones/tablets, one strategy to ensure the best quality is to record from the rear-facing camera as it has a higher video frame rate. This approach may be particularly useful during asynchronous video visits or when patient assistance is readily available during live visits. For the technologically savvy user, 2 cameras can provide a close-up highresolution/high frame rate eye movement recording (phone rear-facing camera) and a wider field of view of the patient (computer or tablet camera). This approach can be especially helpful during the evaluation of positional vertigo, as the position of the head can be seen from the camera with a wider field of view (figure 2 and video 1 ). Furthermore, if the pattern of positional vertigo fits with a diagnosis of benign paroxysmal positional vertigo (BPPV), one can guide the patient immediately through treatment during the remote visit. Finally, mobile applications can be used to facilitate the virtual ocular motor and vestibular examination. ${ }^{8}$

\section{The Key Components of a Focused History}

A focused history highlighting timing, triggers, and risk factors is key to the triaging process (table 1). ${ }^{9}$ The provider should ask whether the symptoms are intermittent or sustained and determine whether the symptoms occur spontaneously or by specific triggers; for example, if BPPV is suspected, careful questioning often confirms the affected canal. ${ }^{10}$ Age, ischemic risk factors, and the presence of associated symptoms also play an important role in triaging. ${ }^{9}$

\section{The Virtual Examination}

Once a focused history has been obtained and patients are appropriately triaged, a targeted virtual examination can help distinguish between peripheral and central causes (table 2). ${ }^{9,11}$ The general appearance of the patient may yield diagnostic information. For example, an abnormal head tilt suggesting utricular imbalance often accompanies a skew deviation, and almost always indicates a central process. A skew can be elicited using a modified alternate cover test with the patient's palm, a close-by person, or other household item acting as an occluding apparatus (figure 2). ${ }^{12}$ Each eye is alternately occluded every 2 to 3 seconds while the patient focuses on the center of the camera, and the examiner looks for a vertical corrective refixation movement.

For virtual assessment of the head impulse test, the patient can be instructed to perform self-generated active head impulses on command, while fixing on a visible target on the screen (table 1 and video 2). A brief instructive demonstration by the examiner is helpful to ensure the correct size and speed of the head impulses. Again, a high enough video frame rate is needed to capture the corrective saccades (figure 1). One must also remember that "active" head impulses may be challenging to apply remotely, and can sometimes mask 
Figure 1 Video Interpretation Simulation

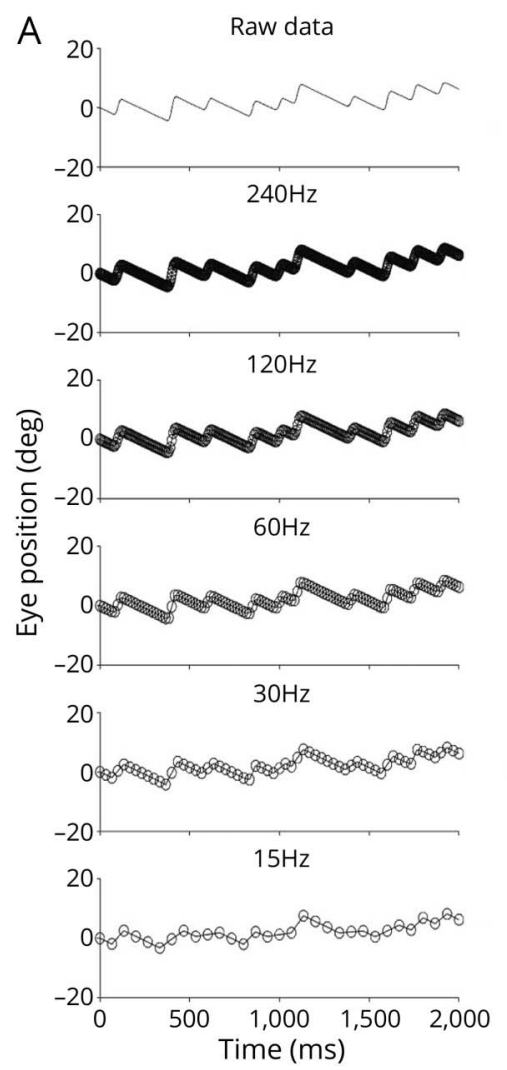

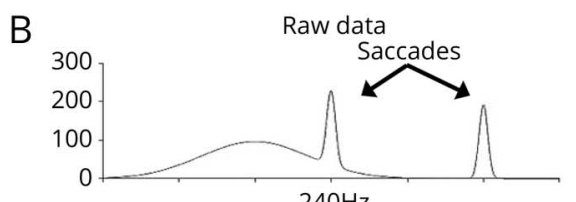
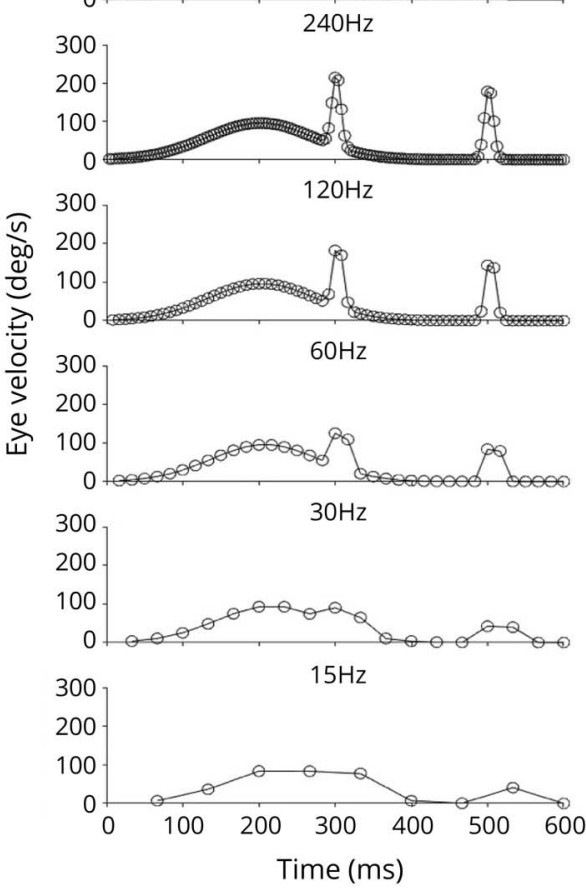

Simulated data show the effect of frame rate on the interpretation of nystagmus $(A)$ and correc tive "catch up" saccades during the head impulse test (B). Jerk nystagmus can still be appreciated at 30 frames per second (fps). At lower frame rates, the distinction between slow phases and quick phases of the nystagmus becomes unclear. For the head impulse test, catch-up saccades appear slower and blend with the video-oculography response at the frame rates of $60 \mathrm{fps}$ or less. Note that this simulated data did not include noise and real data collected from a patient will also include some level of noise that may require a higher frame rate.

Figure 2 The Virtual Examination

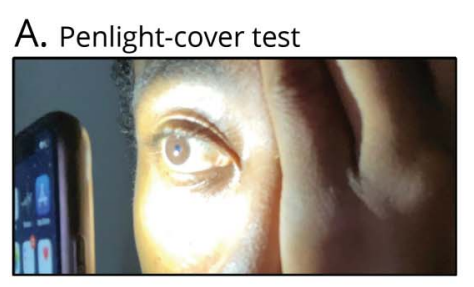

\section{B. Alternate-cover test}

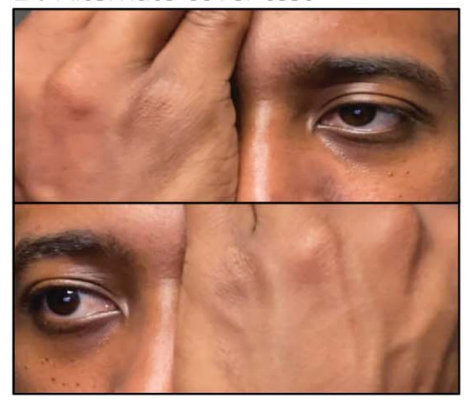

C
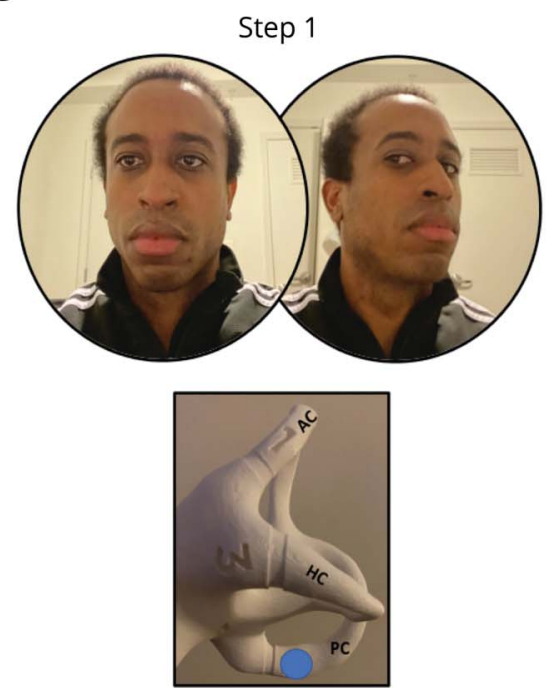

Step 2
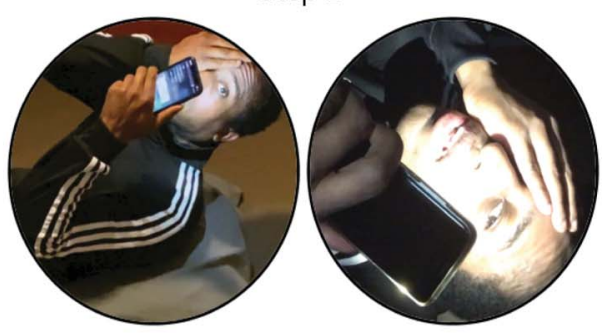

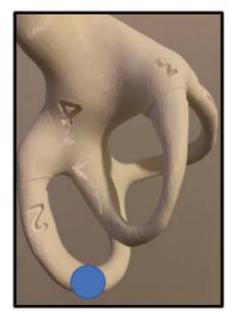

(A) A modified version of the penlight-cover test, where the patient's cell phone serves the dual purpose of a camera and a light source, essentially creating a makeshift video-oculography device. (B) A modified version of the alternate-cover test by performing alternating monocular occlusion using the palm for 2-3 seconds at a time at the command from provider. (C) Virtual Dix-Hallpike maneuver using the modified penlight cover test. The patient turns the head $45^{\circ}$ to one side while seated (left side is shown here), and then moves en bloc straight back with head slightly hyperextended at about $30^{\circ}$. Blue dots simulate moving otoconia within the posterior semicircular canal during the maneuver. $\mathrm{AC}=$ anterior canal; $\mathrm{HC}=$ horizontal canal; $\mathrm{PC}=$ posterior canal. 
Table 1 Key History and Examination Findings in the Main 5 Differential Diagnoses of an Acute Vertigo Presentation

\begin{tabular}{|c|c|c|}
\hline \multirow[b]{2}{*}{ Diagnosis } & \multicolumn{2}{|l|}{ Key findings } \\
\hline & History & Virtual examination \\
\hline Vestibular neuritis & $\begin{array}{l}\text { - AVS } \\
\text { - No hearing symptoms } \\
\text { - Preceding viral illness }\end{array}$ & $\begin{array}{l}\text { - Spontaneous unilateral mixed horizontal-torsional nystagmus } \\
\text { that increases with fixation removal } \\
\text { - Contralaterally directed corrective saccades with active HIT }\end{array}$ \\
\hline Stroke & $\begin{array}{l}\text { - AVS } \\
\text { - Associated neurologic symptoms } \\
\text { - Acute unilateral hearing loss/tinnitus } \\
\text { - Vascular risk factors }\end{array}$ & $\begin{array}{l}\text { - Direction-changing, gaze-evoked, or pure vertical/torsional } \\
\text { nystagmus } \\
\text { - Skew deviation or head tilt } \\
\text { - Normal or abnormal HIT } \\
\text { - Unilateral hearing loss }\end{array}$ \\
\hline Vestibular migraines & $\begin{array}{l}\text { - Episodic vertigo (spontaneous or triggered) } \\
\text { - Headache plus migrainous features } \\
\text { - Aural symptoms }\end{array}$ & - Normal examination or persistent positional nystagmus \\
\hline Ménière disease & $\begin{array}{l}\text { - Recurrent spontaneous episodic vertigo } \\
\text { - Fluctuating hearing loss } \pm \text { other aural symptoms } \\
\text { - Lermoyez syndrome (hearing improves as vertigo begins) } \\
\text { - Drop attacks }\end{array}$ & $\begin{array}{l}\text { - Spontaneous mixed horizontal-torsional nystagmus that may } \\
\text { change direction }\end{array}$ \\
\hline BPPV & - Transient positional vertigo & $\begin{array}{l}\text { - Upbeat-torsional nystagmus (pcBPPV); geotropic or } \\
\text { apogeotropic nystagmus (hcBPPV) }\end{array}$ \\
\hline
\end{tabular}

Abbreviations: AVS = acute vestibular syndrome; BPPV = benign paroxysmal positional vertigo; hcBPPV = horizontal canal benign paroxysmal positional vertigo; HIT = head impulse test; pcBPPV = posterior canal benign paroxysmal positional vertigo.

vestibular hypofunction. ${ }^{13,14}$ If available, mobile-based quantitative VOG may provide a more accurate assessment. ${ }^{8}$

Spontaneous jerk nystagmus is the hallmark of vestibular imbalance and is best appreciated when the patient is close to the device with eyes fully illuminated and focusing on the camera. Because peripheral nystagmus becomes more intense with gaze in the direction of quick phase (Alexander law), and characteristically increases or only appears when visual fixation is eliminated, ${ }^{15}$ a simple strategy to remove fixation is to ask the patient to close the eyes and observe for movement of the corneal bulges. ${ }^{15}$ The effect of fixation on nystagmus can also be simulated using a modified version of the penlight cover test. ${ }^{16}$ In this modified technique, the phone's flashlight serves the dual role of camera and light source, while the patient or a family member occludes the other eye (figure 2 and video 3). When BPPV is suspected, the patient can be instructed to perform positional maneuvers while a smartphone/tablet is held close to the eyes, either by the patient or a family member (figure 2 and video 1). When possible, the modified penlight cover test can be applied to better appreciate the nystagmus. The velocity of the nystagmus also affects one's ability to appreciate it remotely, therefore video frame rate and Internet connectivity become extremely important. The severity of symptoms and the availability of assistance during the evaluation can also affect the usefulness of these techniques. During asynchronous video visits, the lack of immediate guidance from the examiner may limit its usefulness.

Table 2 Step-by-Step Instruction for the Virtual HINTS (Head Impulse Test, Nystagmus Evaluation, and Test of Skew) Examination

\begin{tabular}{|c|c|}
\hline Examination & Description \\
\hline $\begin{array}{l}\text { Command-driven active head } \\
\text { impulse test }\end{array}$ & $\begin{array}{l}\text { - Instruct patient to move close to the camera with eyes fully illuminated } \\
\text { - Provider directs patient to fixate on a visual target on the device and perform head impulse test in the yaw plane at } \\
\text { the direction of the provider }\end{array}$ \\
\hline Nystagmus & $\begin{array}{l}\text { Fixation } \\
\text { - Instruct patient to move close to the camera with eyes fully illuminated } \\
\text { - Instruct patient to stare straight ahead at the camera, then assess for nystagmus (for down and down/lateral gazes, } \\
\text { instruct patient/family member to elevate eyelids to ensure visualization of the eyes) } \\
\text { Fixation removal } \\
\text { Modified penlight cover test: } \\
\text { - Instruct patient/family member to perform monocular occlusion using palm } \\
\text { - Instruct patient/family member to remove visual fixation by shining a flashlight (preferably a cellphone flashlight) in } \\
\text { the eye opposite } \\
\text { or } \\
\text { - Evaluate nystagmus under closed eyelids by looking at the corneal bulges }\end{array}$ \\
\hline $\begin{array}{l}\text { Alternate-cover test (test of } \\
\text { skew) }\end{array}$ & $\begin{array}{l}\text { - Instruct patient to move close and focus on the camera (fixation target) with eyes fully illuminated } \\
\text { - Instruct patient/family member to perform alternating monocular occlusion using palm for } 2-3 \text { seconds at a time at } \\
\text { the command from provider }\end{array}$ \\
\hline
\end{tabular}


Hearing evaluation and assessment of balance combined with the 3-step HINTS (Head Impulse test, Nystagmus evaluation, and Test of Skew) or HINTS plus have a higher sensitivity and specificity than neuroimaging for detecting strokes. ${ }^{17,18} \mathrm{~A}$ crude Weber test can be performed by the patient tapping the incisors then reporting whether the sound is equal or louder from one ear. There are also various app-based screening tools (e.g., the hearWHO app [WHO, Geneva, Switzerland]) that can be deployed. Self-assessment of hearing is often unreliable.

Both the virtual HINTS and Dix-Hallpike examinations can be readily applied via telemedicine. For the most effective evaluation, the video quality, lighting condition, and distance from the recording device are the most important considerations. Further studies validating the clinical utility of these techniques will be necessary for standardization and to spur the development of virtual and augmented reality solutions for more realistic telemedicine assessments.

\section{Study Funding}

No targeted funding reported.

\section{Disclosure}

K.E. Green, J.M. Pogson, J. Otero-Millan, D.R. Gold, N. Tevzadze, and A.S. Saber Tehrani report no disclosures. D.S. Zee received royalties from Oxford University Press. D.E. Newman-Toker has received personal compensation for consulting, serving on a scientific advisory board, speaking, or other activities and is a frequent speaker at outside academic institutions and receives modest/standard honoraria and travel costs (e.g., grand rounds, CME lectures); has received research support from GN Otometrics, which has loaned research equipment; the company has also paid the institution for an option to license diagnostic decision support technology that could be used to enhance their existing VOG device technology. A. Kheradmand reports no disclosures. Go to Neurology.org/N for full disclosures.

\section{Appendix Authors}

\begin{tabular}{|c|c|c|}
\hline Name & Location & Contribution \\
\hline $\begin{array}{l}\text { Kemar E. } \\
\text { Green, DO }\end{array}$ & $\begin{array}{l}\text { Johns Hopkins } \\
\text { University School of } \\
\text { Medicine, Baltimore }\end{array}$ & $\begin{array}{l}\text { Designed and conceptualized } \\
\text { study, drafted the manuscript } \\
\text { for intellectual content, major } \\
\text { role in intellectual and content } \\
\text { contribution }\end{array}$ \\
\hline
\end{tabular}

\begin{tabular}{lll}
\hline $\begin{array}{l}\text { Jacob M. } \\
\text { Pogson, } \\
\text { MClinAud, } \\
\text { PhD }\end{array}$ & $\begin{array}{l}\text { Johns Hopkins } \\
\text { University School of } \\
\text { Medicine, Baltimore }\end{array}$ & $\begin{array}{l}\text { Major role in intellectual and } \\
\text { content contribution, revised } \\
\text { manuscript for intellectual } \\
\text { content }\end{array}$ \\
\hline $\begin{array}{l}\text { Jorge Otero- } \\
\text { Millan, PhD }\end{array}$ & $\begin{array}{l}\text { Johns Hopkins } \\
\text { University School of } \\
\text { Medicine, Baltimore }\end{array}$ & $\begin{array}{l}\text { Major role in intellectual and } \\
\text { content contribution, revised } \\
\text { manuscript for intellectual } \\
\text { content }\end{array}$ \\
\hline $\begin{array}{l}\text { Daniel R. } \\
\text { Gold, DO }\end{array}$ & $\begin{array}{ll}\text { Johns Hopkins } \\
\text { University School of } \\
\text { Medicine, Baltimore }\end{array}$ & $\begin{array}{l}\text { Major role in intellectual and } \\
\text { content contribution }\end{array}$ \\
& & \\
\hline
\end{tabular}

Appendix (continued)

\begin{tabular}{|c|c|c|}
\hline Name & Location & Contribution \\
\hline $\begin{array}{l}\text { Nana } \\
\text { Tevzadze, MD, } \\
\text { PhD }\end{array}$ & $\begin{array}{l}\text { Johns Hopkins } \\
\text { University School of } \\
\text { Medicine, Baltimore }\end{array}$ & $\begin{array}{l}\text { Major role in intellectual and } \\
\text { content contribution }\end{array}$ \\
\hline $\begin{array}{l}\text { Ali S. Saber } \\
\text { Tehrani, MD }\end{array}$ & $\begin{array}{l}\text { Johns Hopkins } \\
\text { University School of } \\
\text { Medicine, Baltimore }\end{array}$ & $\begin{array}{l}\text { Major role in intellectual and } \\
\text { content contribution }\end{array}$ \\
\hline $\begin{array}{l}\text { David S. Zee, } \\
\text { MD }\end{array}$ & $\begin{array}{l}\text { Johns Hopkins } \\
\text { University School of } \\
\text { Medicine, Baltimore }\end{array}$ & $\begin{array}{l}\text { Major role in intellectual and } \\
\text { content contribution }\end{array}$ \\
\hline $\begin{array}{l}\text { David E. } \\
\text { Newman- } \\
\text { Toker, MD, } \\
\text { PhD }\end{array}$ & $\begin{array}{l}\text { Johns Hopkins } \\
\text { University School of } \\
\text { Medicine, Baltimore }\end{array}$ & $\begin{array}{l}\text { Major role in intellectual and } \\
\text { content contribution }\end{array}$ \\
\hline $\begin{array}{l}\text { Amir } \\
\text { Kheradmand, } \\
\text { MD }\end{array}$ & $\begin{array}{l}\text { Johns Hopkins } \\
\text { University School of } \\
\text { Medicine, Baltimore }\end{array}$ & $\begin{array}{l}\text { Design and conceptualized } \\
\text { study, drafted the manuscript } \\
\text { for intellectual content, major } \\
\text { role in intellectual and content } \\
\text { contribution }\end{array}$ \\
\hline
\end{tabular}

\section{References}

1. Newman-Toker DE, Hsieh YH, Camargo CA, Pelletier AJ, Butchy GT, Edlow JA Spectrum of dizziness visits to US emergency departments: cross-sectional analysis from a nationally representative sample. Mayo Clin Proc 2008;83:765-775.

2. Zee D, Newman-Toker D, Tourkevich R, et al. Diagnostic impact of a device-enabled remote "tele-dizzy" consultation service. Neurology 2020;94:58.

3. Shaikh AG, Bronstein A, Carmona $\mathrm{S}$, et al. Consensus on virtual management of vestibular disorders: urgent versus expedited care. Cerebellum [online serial] Epub 2020 Aug 14. Available at: link.springer.com/10.1007/s12311-020-01178-8. Accessed August 20, 2020.

4. Hammersley V, Donaghy E, Parker R, et al. Comparing the content and quality of video, telephone, and face-to-face consultations: a non-randomised, quasiexperimental, exploratory study in UK primary care. Br J Gen Pract J R Coll Gen Pract 2019;69:e595-e604.

5. Rao SP, Jayant NS, Stachura ME, Astapova E, Pearson-Shaver A. Delivering diagnostic quality video over mobile wireless networks for telemedicine. Int J Telemed Appl 2009;2009:406753.

6. McConnochie KM, Conners GP, Brayer AF, et al. Differences in diagnosis and treatment using telemedicine versus in-person evaluation of acute illness. Ambul Pediatr 2006;6:187-195.

7. Bauerly BC, McCord RF, Hulkower R, Pepin D. Broadband Access as a public Health issue: the role of law in expanding broadband access and connecting underserved communities for better health outcomes. J L Med Ethics 2019;47:39-42.

8. Parker T, Farrell N, Otero-Millan J, Kheradmand A, McClenney A, Newman-Toker D. Video Head Impulse Testing Using a Novel "Eyephone" App. XXXI Bárány Society Meeting; 2020.

9. Newman-Toker DE, Edlow JA. TiTrATE: a novel, evidence-based approach to diagnosing acute dizziness and vertigo. Neurol Clin 2015;33:577-599, viii.

10. Kim HJ, Song JM, Zhong L, Yang X, Kim JS. Questionnaire-based diagnosis of benign paroxysmal positional vertigo. Neurology 2020;94:e942-e949.

11. Kattah JC, Talkad AV, Wang DZ, Hsieh YH, Newman-Toker DE. HINTS to diagnose stroke in the acute vestibular syndrome: three-step bedside oculomotor examination more sensitive than early MRI diffusion-weighted imaging. Stroke 2009;40: 3504-3510.

12. Moss $\mathrm{H}$, Beres $\mathrm{S}$. Visual system examination during video visits: eye movement exam [online]. YouTube. Available at: youtube.com/watch?v=Yv9edG1ms2o. Accessed May 20, 2020.

13. Black RA, Halmagyi GM, Thurtell MJ, Todd MJ, Curthoys IS. The active head impulse test in unilateral peripheral vestibulopathy. Arch Neurol 2005;62:290-293.

14. Della Santina CC, Cremer PD, Carey JP, Minor LB. Comparison of head thrust test with head autorotation test reveals that the vestibulo-ocular reflex is enhanced during voluntary head movements. Arch Otolaryngol Head Neck Surg 2002;128:1044-1054

15. Leigh RJ, Zee DS. The Neurology of Eye Movements. 5th ed. Oxford: Oxford University Press; 2015.

16. Newman-Toker DE, Sharma P, Chowdhury M, Clemons TM, Zee DS, Della Santina CC. Penlight-cover test: a new bedside method to unmask nystagmus. J Neurol Neurosurg Psychiatry 2009;80:900-903.

17. Newman-Toker DE, Kerber KA, Hsieh YH, et al. HINTS outperforms ABCD2 to screen for stroke in acute continuous vertigo and dizziness. Acad Emerg Med Off J Soc Acad Emerg Med 2013;20:986-996.

18. Carmona S, Martínez C, Zalazar G, et al. The diagnostic accuracy of truncal ataxia and HINTS as cardinal signs for acute vestibular syndrome. Front Neurol 2016;7:125. 


\section{Neurology}

\section{Opinion and Special Articles: Remote Evaluation of Acute Vertigo: Strategies and Technological Considerations}

Kemar E. Green, Jacob M. Pogson, Jorge Otero-Millan, et al. Neurology 2021;96;34-38 Published Online before print October 1, 2020

DOI 10.1212/WNL.0000000000010980

This information is current as of October 1, 2020

\section{Updated Information \& Services \\ References \\ Citations \\ Subspecialty Collections}

Errata

Permissions \& Licensing

Reprints including high resolution figures, can be found at: http://n.neurology.org/content/96/1/34.full

This article cites 14 articles, 3 of which you can access for free at: http://n.neurology.org/content/96/1/34.full\#ref-list-1

This article has been cited by 3 HighWire-hosted articles: http://n.neurology.org/content/96/1/34.full\#\#otherarticles

This article, along with others on similar topics, appears in the following collection(s):

Nystagmus

http://n.neurology.org/cgi/collection/nystagmus

Vertigo

http://n.neurology.org/cgi/collection/vertigo

An erratum has been published regarding this article. Please see next page or:

/content/97/9/459.2.full.pdf

Information about reproducing this article in parts (figures,tables) or in its entirety can be found online at:

http://www.neurology.org/about/about_the_journal\#permissions

Information about ordering reprints can be found online:

http://n.neurology.org/subscribers/advertise

Neurology ${ }^{\circledR}$ is the official journal of the American Academy of Neurology. Published continuously since 1951, it is now a weekly with 48 issues per year. Copyright @ 2020 American Academy of Neurology. All rights reserved. Print ISSN: 0028-3878. Online ISSN: 1526-632X.

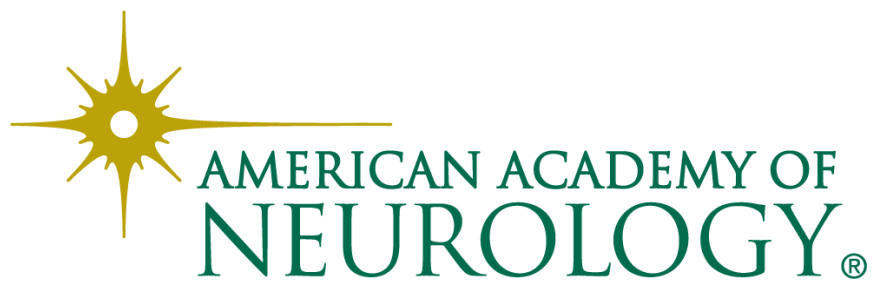




\section{Disputes \& Debates: Editors' Choice}

Steven Galetta, MD, FAAN, Editor

Aravind Ganesh, MD, DPhil, FRCPC, Deputy Editor

Ariane Lewis, MD, Deputy Editor

James E. Siegler III, MD, Deputy Editor

\section{Editors' Note: Scan-Negative Cauda Equina Syndrome: A Prospective Cohort Study}

Using prospectively collected data from their neurosurgical referral center, Dr. Hoeritzauer et al. summarize their observations regarding patients with cauda equina syndrome (CES), with and without imaging confirmation. Among patients in this cohort, 69\% lacked radiographic evidence of cauda equina compression and were referred to as "scan-negative" (normal MRI) or "mixed" (root enhancement without cauda compression). History or presence of functional symptoms, along with normal patellar reflexes, more severe pain, and panic attack at presentation were associated with a "scan-negative" condition. It is of interest that disturbances of urine or bowel function were no less common among patients with "scan-negative" CES. Dr. Amelot and colleagues highlight the importance of follow-up and education for patients at risk of CES (e.g., those with pre-existing disk disease). They also suggest that patients with scan-negative CES may be vulnerable to underlying somatization or anxiety over the threat of possible neurologic dysfunction. In response, Dr. Hoeritzauer et al. affirm that even patients with "scan-negative" CES were followed for several years after their initial presentation to evaluate the cause of their symptoms. Furthermore, the investigators maintain the objective of their study was to determine risk factors for "scan-negative" vs "scan-positive" CES, which includes functional neurologic disease, medications, pain, and panic. The investigators have referred clinicians and patients to their fact sheet on "scan-negative" CES for more information. Professor Beucler also emphasizes the clinical presentation of CES typically begins with radicular pain, followed by motor and later bowel or bladder symptoms.

James E. Siegler III, MD, and Steven Galetta, MD

Neurology ${ }^{\circledR}$ 2021;97:455. doi:10.1212/WNL.0000000000012501

\section{Reader Response: Scan-Negative Cauda Equina Syndrome: A Prospective Cohort Study}

Aymeric Amelot (Tours, France), Alexia Planty-Bonjour (Tours, France), and Louis-Marie Terrier (Tours, France) Neurology ${ }^{\circledR}$ 2021;97:455-456. doi:10.1212/WNL.0000000000012502

We read with great interest the article by Hoeritzauer et al. ${ }^{1}$ This work could develop into both a reference and a warning concerning the difficulty in approaching a CES diagnosis. The preeminent result was that only $24 \%$ of their patients had a "scan-positive" CES.

In fact, to suggest a potential alternative explanation for "scan-negative CES," we believe that it would be interesting to determine the proportion of patients who were followed by a spine specialist ( $81 \%$ of the patients in their series suffered from pain or lower back pain). Indeed, a CES prognosis is dramatic, with highly disabling long-term dysfunction sequelae, ${ }^{2}$ and is feared by all specialists. Furthermore, it develops in most of cases from pre-existing vertebral disk disease. $^{3}$ 
Although emergency interventions are in favor of improved outcomes, the only true effectiveness on outcome lies within the education and prevention of patients concerning the clinical signs that should be tracked down and consulted for the slightest appearance of deficit, genitosphincter disorders, or hyperalgesia.

We believe that for patients who are psychiatrically vulnerable (>80\% in the "scan-negative CES" group of Hoeritzauer et al.), living in a climate of anxiety and hyperawareness of the threat that CES represents may promote somatization and other mental health manifestations. In this group, it would not be surprising to identify patients presenting several "scan-negative CES" alerts.

1. Hoeritzauer I, Carson A, Statham P, et al. Scan-negative cauda equina syndrome: a prospective cohort study. Neurology. 2021;96(3): e433-e447.

2. Korse NS, Veldman AB, Peul WC, Vleggeert-Lankamp CLA. The long term outcome of micturition, defecation and sexual function after spinal surgery for cauda equina syndrome. PLoS One. 2017;12(4):e0175987.

3. Korse NS, Jacobs WCH, Elzevier HW, Vleggeert-Lankamp CLA. Complaints of micturition, defecation and sexual function in cauda equina syndrome due to lumbar disk herniation: a systematic review. Eur Spine J. 2013;22(5):1019-1029.

Copyright $\odot 2021$ American Academy of Neurology

\section{Author Response: Scan-Negative Cauda Equina Syndrome: A Prospective Cohort Study}

Ingrid Hoeritzauer (Edinburgh), Alan Carson (Edinburgh), Patrick Statham (Edinburgh),

Andreas Demetriades (Edinburgh), and Jon Stone (Edinburgh)

Neurology ${ }^{\circledR}$ 2021;97:456-457. doi:10.1212/WNL.0000000000012503

We thank Dr. Amelot et al. for the response to our article. ${ }^{1}$ We are aware that in other centers only patients with positive scans are referred to neurosurgeons. In our center, and in most of the UK National Health Service system, "suspected cauda equina syndrome (CES)" cases are seen by out-ofhours neurosurgery services for urgent transfer and MRI scanning. The proportion of patients with a scan-positive CES (47/198 or 24\%) was consistent with a systematic review $(19 \%)^{2}$ and our retrospective study $(28 \%)^{3}$

We think the authors have possibly misunderstood the primary purpose of our study which was especially focused on describing what is wrong with the large majority of such patients with "scan-negative" CES presentations. ${ }^{4}$

We do not agree that follow-up with a specific spinal specialist might have altered our outcome data. All patients were referred to a neurosurgeon who assessed their clinical and radiologic findings for evidence of "scan-positive" CES. The 137 patients in the mixed and "scan-negative" CES groups had follow-up for an average of 24 months, looking for any new neurologic or neurosurgical diagnoses that fully or partially explained their CES symptoms. Our patients with persisting neurologic symptoms continued to have spinal specialist input from a neurosurgeon or neurologist. No patients in the mixed or "scannegative" CES groups had a presentation with "scan-positive" CES during follow-up, which is meaningful given that nearly all patients would present to local NHS services.

We do not agree with the framing of functional neurologic disorder or somatization as reattributed distress. Functional disorders are distinct entities in their own right, to which pathophysiologic and predictive cognitive processes, medications and iatrogenic factors contribute.,

In our article, we hypothesize that pain, panic, medications, previous bladder dysfunction, or functional neurologic disorders may cause patients to present with "scan-negative" CES. 
We recently created a patient factsheet, available on neurosymptoms.org (see bladder symptoms), that explains our current thinking about "scan-negative" CES. This may be helpful for patients who are left wondering what has caused their symptoms when their scans are normal.

Further research into this neglected group is required. We are glad to have interest from neurosurgeons because we try to increase awareness and optimize treatment of this group.

1. Hoeritzauer I, Carson A, Statham P, et al. Scan-negative cauda equina syndrome: a prospective Cohort study. Neurology. 2021;96(3):e433-e447.

2. Hoeritzauer I, Wood M, Copley PC, Demetriades AK, Woodfield J. What is the incidence of cauda equina syndrome? a systematic review. J Neurosurg Spine. 2020;14:1-10.

3. Hoeritzauer I, Pronin S, Carson A, Statham P, Demetriades AK, Stone J. The clinical features and outcome of scan-negative and scanpositive cases in suspected cauda equina syndrome: a retrospective study of 276 patients. J Neurol. 2018;265(12):2916-2926.

4. Gibson LL, Harborow L, Nicholson T, Bell D, David AS. Is scan-negative cauda equina syndrome a functional neurological disorder? a pilot study. Eur J Neurol. 2020;27(7):1336-1342.

5. Bègue I, Adams C, Stone J, Perez DL. Structural alterations in functional neurological disorder and related conditions: a software and hardware problem? Neuroimage Clin. 2019;22:101798.

6. Van den Bergh O, Witthöft M, Petersen S, Brown RJ. Symptoms and the body: taking the inferential leap. Neurosci Biobehav Rev. 2017; 74(pt A):185-203.

Copyright (C) 2021 American Academy of Neurology

\title{
Reader Response: Scan-Negative Cauda Equina Syndrome: A Prospective Cohort Study
}

\author{
Nathan Beucler (Toulon, France) \\ Neurology ${ }^{\circledR}$ 2021;97:457. doi:10.1212/WNL.0000000000012504
}

Hoeritzauer et al. ${ }^{1}$ prospectively investigated the clinical presentation of 184 patients admitted for clinical suspicion of CES, among which 47 (25\%) suffered from cauda equina (CE) compression on MRI, whereas 76 (41\%) only showed single nerve root compression and 61 (33\%) did not show any sign of compression. I congratulate the authors as they showed that approximately one-third of the patients $(33 \%, 61 / 184)$ admitted for suspicion of CES possibly suffer from multifactorial pre-existing organic and functional disorders, including bladder dysfunction.

I would like to clarify the clinical presentation of CES. Unilateral or bilateral sciatica is usually the first symptom, followed by neurologic deficits of the lower limbs. ${ }^{2,3}$ Saddle anesthesia and urinary or fecal incontinence are delayed symptoms and are usually associated with a worse prognosis. ${ }^{2,3}$ This published study is in line with previous reports that patients with CE compression on MRI were more likely to present sciatica ( $83 \%$ vs $44 \%$ ) and bilateral reduced or absent ankle jerk reflexes ( $78 \%$ vs $12 \%$ ), equally likely to present perineal symptoms, and less likely to present uncontrollable back pain ( $41 \%$ vs $70 \%)$ or symptoms of panic attack ( $37 \%$ vs $70 \%)$ compared with patients with no CE compression on MRI.

Alongside clinical presentation suggestive of CES, an emergency MRI of the lumbosacral spine remains necessary to assess any mechanical cause for the symptoms. ${ }^{4}$ Nevertheless, in my opinion, clinicians should be taught to give rise to the diagnosis of CES in face with bilateral sciatica, with or without neurologic deficits or perineal symptoms.

1. Hoeritzauer I, Carson A, Statham P, et al. Scan-negative cauda equina syndrome: a prospective cohort study. Neurology. 2021;96(3): e433-e447.

2. Long B, Koyfman A, Gottlieb M. Evaluation and management of cauda equina syndrome in the emergency department. Am J Emerg Med. 2020;38(1):143-148.

3. Todd NV. Guidelines for cauda equina syndrome. Red flags and white flags. Systematic review and implications for triage. Br J Neurosurg. 2017;31(3):336-339.

4. Dionne N, Adefolarin A, Kunzelman D, et al. What is the diagnostic accuracy of red flags related to cauda equina syndrome (CES), when compared to Magnetic Resonance Imaging (MRI)? A systematic review. Musculoskelet Sci Pract. 2019;42:125-133.

Copyright (c) 2021 American Academy of Neurology

Author disclosures are available upon request (journal@neurology.org). 
Editors' Note: Association of Age at Onset and First Symptoms With

Disease Progression in Patients With Metachromatic

\section{Leukodystrophy}

Metachromatic leukodystrophy is a neurodegenerative condition with a variable rate of progression that warrants more systematic investigation. In their natural history study of 98 patients with metachromatic leukodystrophy, Dr. Kehrer et al. summarize the prominent symptoms and age of symptom onset according to various forms of the illnesses (late infantile, early juvenile, late juvenile, and adult). In younger persons (under age 6 years), motor manifestations with or without cognitive impairment were common, whereas in late juvenile and adult forms, cognitive symptoms became increasingly common. Patients with earlier disease onset experienced more rapid progression. Dr. Michell-Robinson and Lépine hypothesize that arylsulfatase A activity (the defective enzyme in metachromatic leukodystrophy) and therefore buildup of toxic sulfatide levels might be related to the severity or progression of the illness. Because some older patients may also experience rapid declines, the investigators do not believe sulfatide toxicity to be the primary mediator of disease severity. They also emphasize the importance of motor system involvement as a driver of neurologic deterioration. Although there is much more to understand about this condition, it is clear now that motor symptom manifestations typically precede rapid disease progression.

\section{Reader Response: Association of Age at Onset and First Symptoms With Disease Progression in Patients With Metachromatic Leukodystrophy}

Mackenzie A. Michell-Robinson (Montreal) and Sarah Lépine (Montreal) Neurology ${ }^{\circledR}$ 2021;97:458. doi:10.1212/WNL.0000000000012506

Kehrer et al. ${ }^{1}$ categorized different onset forms of metachromatic leukodystrophies based on first symptoms at onset and disease progression. The genotypes associated with each of these categories seem to indicate that earlier symptom onset is associated with more severe arylsulfatase A (ARSA) deficiency.

Based on the findings of Kehrer et al., we wonder whether ARSA activity is the factor specifying disease onset based on the rate of sulfatide accumulation in tissues, whereas the neurologic manifestations at onset are determined by the system that is most vulnerable when these levels have reached some threshold. Late infantile and early juvenile stages were associated with a higher proportion of patients presenting with motor features at onset, whereas late juvenile and adult forms were associated with higher proportions of patients presenting with cognitive features at onset. In the earlier stages, motor systems are in a critical period of development, whereas cognitive development becomes increasingly important in later stages. Both processes are associated with myelination as an important factor-a process that is known to be affected by the accumulation of sulfatides in the brain. We hoped the authors would comment on this hypothesis based on their understanding of the data.

1. Kehrer C, Elgün S, Raabe C, et al. Association of age at onset and first symptoms with disease progression in patients with metachromatic leukodystrophy. Neurology. 2021;96(2):e255-e266. 


\section{Author Response: Association of Age at Onset and First Symptoms With Disease Progression in Patients With Metachromatic Leukodystrophy}

Samuel Groeschel (Tübingen, Germany) and Ingeborg Krägeloh-Mann (Tübingen, Germany) Neurology ${ }^{\circledR} 2021 ; 97: 459$. doi:10.1212/WNL.0000000000012507

We are grateful for the interest in our article. ${ }^{1}$ Michell-Robinson and Lépine suggest that the different types of symptoms at disease onset might partly be explained by an age- or maturationspecific vulnerability of motor and cognitive brain networks, for example, their myelination. Indeed, myelination of short-range fibers happens later than of long range. ${ }^{2}$ However, this does not explain the finding in our study that a disease course with a motor onset and rapid progression can occur at all ages, including late-juvenile and adult forms.

In addition, in patients with cognitive onset type and slower disease progression, we have previously shown that there is widespread deep white matter involvement at the time of diagnosis, thus involving long-range fibers but sparing the central region with the primary motor system. ${ }^{3}$ This would argue for a differential involvement of the motor system in these 2 forms of metachromatic leukodystrophies. Once the motor network is primarily affected, rapid neurologic deterioration occurs, which then includes the cognitive system-this seems independent of age of disease onset. The origin of this differential involvement remains unclear, yet our data indicate that a genetic basis could play a role.

1. Kehrer C, Elgün S, Raabe C, et al. Association of age at onset and first symptoms with disease progression in patients with metachromatic leukodystrophy. Neurology. 2021;96(2):e255-e266.

2. Ouyang M, Kang H, Detre JA, Roberts TPL, Huang H. Short-range connections in the developmental connectome during typical and atypical brain maturation. Neurosci Biobehav Rev. 2017;83:109-122.

3. Strölin M, Krägeloh-Mann I, Kehrer C, Wilke M, Groeschel S. Demyelination load as predictor for disease progression in juvenile metachromatic leukodystrophy. Ann Clin Transl Neurol. 2017;4(6):403-410.

Copyright (c) 2021 American Academy of Neurology

\section{CORRECTION}

\section{Opinion and Special Articles: Remote Evaluation of Acute Vertigo} Strategies and Technological Considerations

Neurology ${ }^{\circledR}$ 2021;97:459. doi:10.1212/WNL.0000000000012239

The article "Opinion and Special Articles: Remote Evaluation of Acute Vertigo: Strategies and Technological Considerations" by Green et al. ${ }^{1}$ was published under the wrong section and should have been published in the Resident \& Fellow Section. The publisher regrets the error.

\section{Reference}

1. Green KE, Pogson JM, Otero-Millan J, et al. Opinion and Special Articles: Remote evaluation of acute vertigo: strategies and technological considerations. Neurology. 2021;96(1):34-38. 